\title{
Microplastics contaminate the deepest part of the world's ocean
}

\author{
X. Peng1, M. Chen ${ }^{1,2}$, S. Chen ${ }^{1 *}$, S. Dasgupta ${ }^{1}$ \\ H. Xu' ${ }^{1}$, K. Ta', M. Du' ${ }^{1}$, J. Li' ${ }^{1}$, Z. Guo', S. Bai ${ }^{1}$
}

Abstract

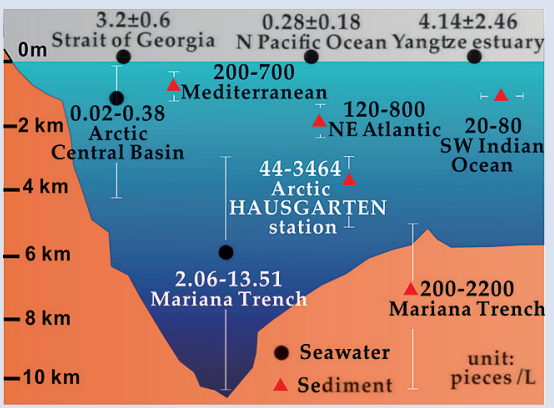

Millions of metric tons of plastics are produced annually and transported from land to the oceans. Finding the fate of the plastic debris will help define the impacts of plastic pollution in the ocean. Here, we report the abundances of microplastic in the deepest part of the world's ocean. We found that microplastic abundances in hadal bottom waters range from 2.06 to 13.51 pieces per litre, several times higher than those in open ocean subsurface water. Moreover, microplastic abundances in hadal sediments of the Mariana Trench vary from 200 to 2200 pieces per litre, distinctly higher than those in most deep sea sediments. These results suggest that manmade plastics have contaminated the most remote and deepest places on the planet. The hadal zone is likely one of the largest sinks for microplastic debris on Earth, with unknown but potentially damaging impacts on this fragile ecosystem.

Received 22 July 2018 | Accepted 29 October 2018 | Published 27 November 2018

\section{Letter}

Plastics are worldwide marine pollutants, accumulating in seawater and sediments (Hammer et al., 2012; Cózar et al., 2014; Ivar do Sul and Costa, 2014). It was estimated that between 4.8 and 12.7 million metric tons of plastic waste entered the ocean in 2010 and this mass could increase by one order of magnitude by 2025 (Jambeck et al., 2015; Geyer et al., 2017). Besides the ocean surface (Thompson et al., 2004; Barnes et al., 2009; Van Sebille et al., 2015; Chae and An, 2017), potential sinks for plastics include deep sea biota (Oliveira et al., 2012), the water column (Courtene-Jones et al., 2017; Kanhai et al., 2018) and sediments (Bergmann et al., 2017), where broken plastics exist as microplastics ( $<5 \mathrm{~mm}$ in size) (Arthur et al., 2009; Hidalgo-Ruz et al., 2012). So far, however, microplastics in the deepest ocean remain largely unexplored.

The hadal zone, which is the deepest region (6000-11000 $\mathrm{m})$ of the oceans lying within trenches, represents 1-2 \% of the global benthic area (Jamieson et al., 2010). Although it was reported that toxic anthropogenic pollutants (e.g., persistent organic pollutants) have reached the deepest ocean on Earth (Jamieson et al., 2017; Dasgupta et al., 2018), little is known about the nature of anthropogenic microplastics in this deep and remote environment. To evaluate the abundance, distribution, and fate of microplastics in the hadal zone, we collected bottom water samples and sediment samples at depths of
2500-11000 m and 5500-11000 m, respectively, from the southern Mariana Trench, where the Challenger Deep, the deepest point on Earth, is situated (Fujioka et al., 2002) (Fig. 1).

Identification by optical microscope and Raman spectrometer confirmed that microplastics are abundant in hadal bottom water (Fig. S-1). The microplastics are fibrous, rod-like, and roundish in shape, and mostly blue, red, white, green, and purple in colour. Plastic microfibres dominate in all the microplastics and are commonly 1-3 $\mathrm{mm}$ in length in seawater samples and mostly $0.1-0.5 \mathrm{~mm}$ in sediment samples (Table S-4). The microplastic abundances in bottom waters range from 2.06 to 13.51 pieces per litre and become more concentrated with depth (Fig. 2) with one exception at depth of 6802 $\mathrm{m}$, reaching 13.51 pieces per litre. At $10903 \mathrm{~m}$, the microplastic abundance reaches 11.43 pieces per litre, which is four times higher than that reported in the subsurface water of open seas, including the NE Pacific Ocean (Desforges et al., 2014), South Pacific subtropical gyre (Eriksen et al., 2013), North Pacific Gyre (Goldstein, 2012), North Atlantic Ocean (Courtene-Jones et al., 2017), and the Arctic Ocean (Bergmann et al., 2017; Kanhai et al., 2018) (Table 1). The high abundance of microplastics in hadal bottom water is also comparable to that reported in coastal waters, for example, in the Yangtze River and the Strait of Georgia, which are regarded as heavily polluted by microplastics (Desforges et al., 2014; Zhao et al., 2014).

\footnotetext{
1. Deep Sea Science Division, Institute of Deep Sea Science and Engineering, Chinese Academy of Sciences, Sanya, Hainan 572000, China

2. Institute of Marine Geology and Resources, Ocean College, Zhejiang University, Zhoushan 316021, China
}

Corresponding author (email: chans@idsse.ac.cn) 


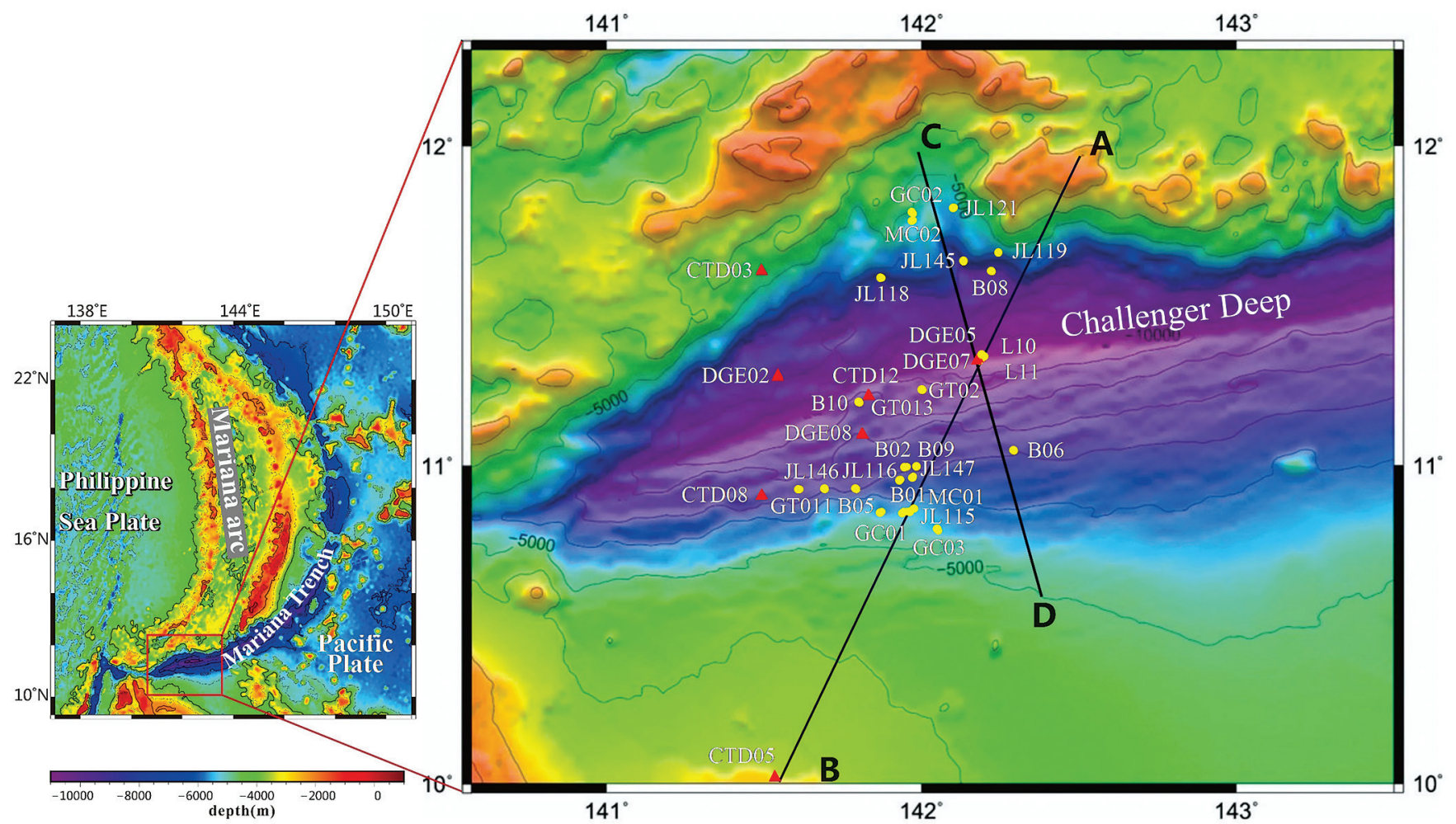

Figure 1 Sampling location map of Mariana Trench seawater (in red triangles) and sediments (in yellow circles). Please see Tables S-1 and S-2 for sampling details.

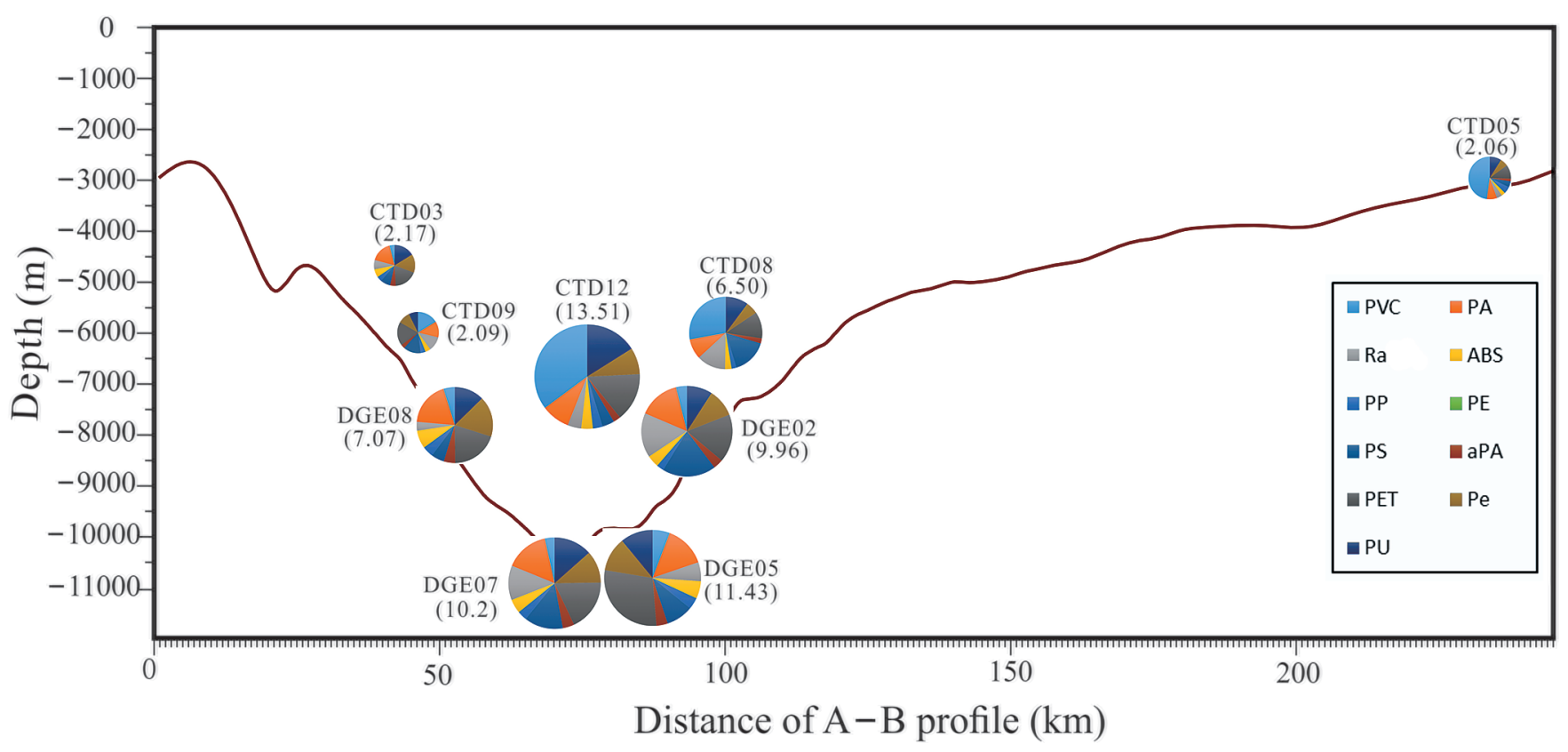

Figure 2 Profile of microplastic abundances and compositions in water samples from Mariana Trench. Pie charts represent the microplastic compositions and numbers in the bracket are the microplastic abundances with units of pieces per litre. PVC-polyvinyl chloride, PA-polyamide, Ra-rayon, ABS-acrylonitrile butadiene styrene, PP-polypropylene, PE-polyethylene, PS-polystyrene, aPAaromatic polyamide, PET-polyethylene terephthalate, Pe-polyester, PU-polyurethane. The $\mathrm{X}$-axis corresponds to the crossline from point $A\left(12{ }^{\circ} \mathrm{N}, 142.5^{\circ} \mathrm{E}\right)$ to point $B\left(9.8^{\circ} \mathrm{N}, 141.43^{\circ} \mathrm{E}\right)$ in Figure 1. 


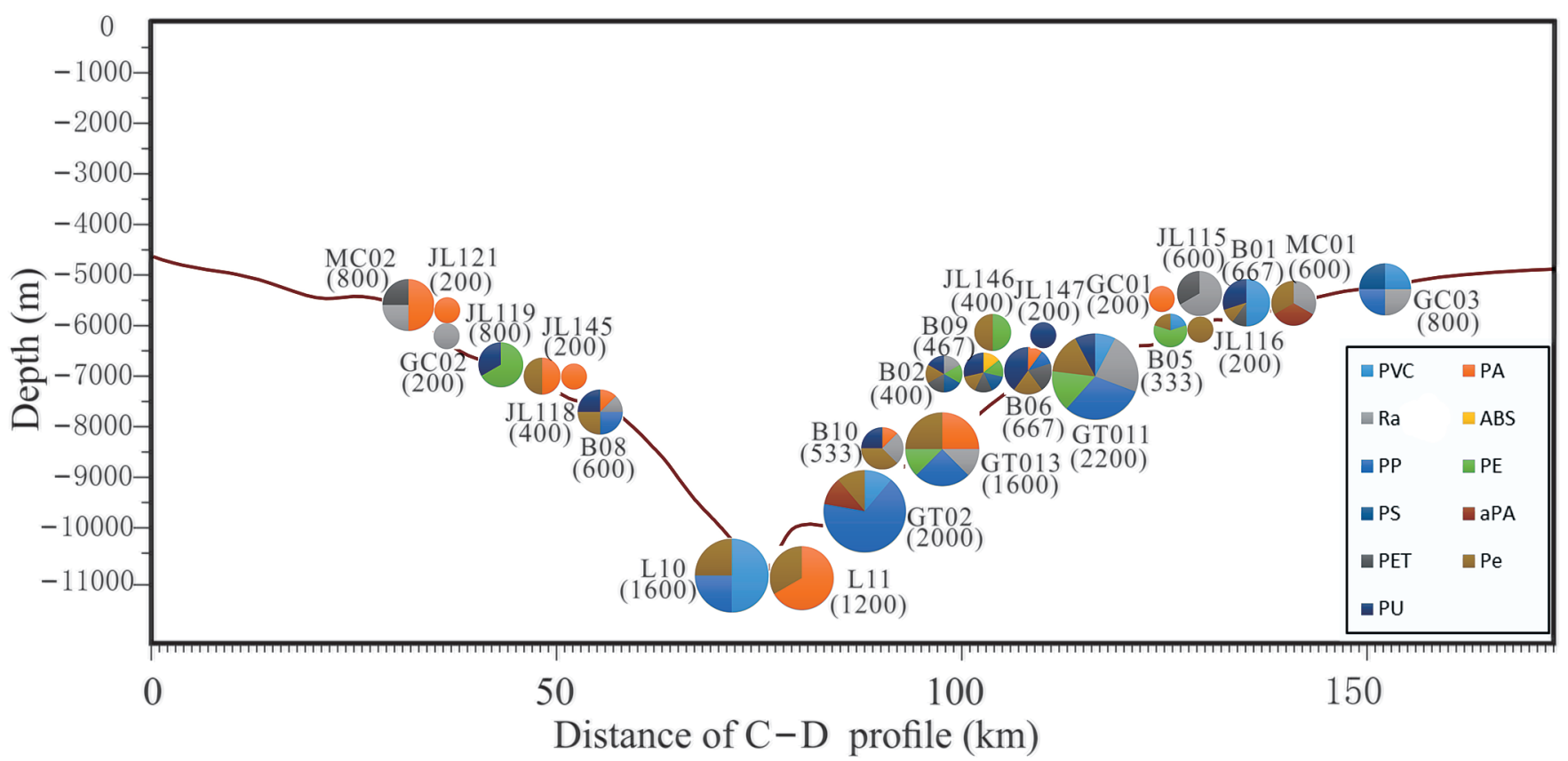

Figure 3 Profile of microplastic abundances and compositions in sediment samples from Mariana Trench. Pie charts represent the microplastic compositions and numbers in the bracket are the microplastic abundances with units of pieces per litre. PVC-polyvinyl chloride, PA-polyamide, Ra-rayon, ABS-acrylonitrile butadiene styrene, PP-polypropylene, PE-polyethylene, PS-polystyrene, aPA-aromatic polyamide, PET-polyethylene terephthalate, Pe-polyester, PU-polyurethane. The X-axis corresponds to the crossline from point $\mathrm{C}\left(12^{\circ} \mathrm{N}, 141.9^{\circ} \mathrm{E}\right)$ to point $\mathrm{D}\left(10.5^{\circ} \mathrm{N}, 141.3^{\circ} \mathrm{E}\right)$ in Figure 1.

Table 1 Abundance of microplastics in seawater and sediments in open oceans worldwide.

\begin{tabular}{|c|c|c|c|c|}
\hline $\begin{array}{l}\text { Sample } \\
\text { type }\end{array}$ & Depth (m) & $\mathrm{p}$ (pieces)/L & Study area & References \\
\hline seawater & 2673-10908 & $2.06-13.51$ & Mariana Trench & This study \\
\hline seawater & 4.50 & $3.20 \pm 0.60$ & Strait of Georgia & $\begin{array}{l}\text { Desforges et al. } \\
\text { (2014) }\end{array}$ \\
\hline seawater & 1 & $4.14 \pm 2.46$ & Yangtze estuary & Zhao et al. (2014) \\
\hline seawater & 1 & $0.02\left(\mathrm{p} / \mathrm{m}^{2}\right)$ & $\begin{array}{c}\text { South Pacific } \\
\text { subtropical gyre }\end{array}$ & $\begin{array}{l}\text { Eriksen et al. } \\
\text { (2013) }\end{array}$ \\
\hline seawater & 4.50 & $0.28 \pm 0.18$ & NE Pacific Ocean & $\begin{array}{l}\text { Desforges et al. } \\
\text { (2014) }\end{array}$ \\
\hline seawater & 2227 & 0.07 & Rockall Trough & $\begin{array}{l}\text { Courtene-Jones } \\
\text { et al. (2017) }\end{array}$ \\
\hline seawater & $50-4369$ & $0.02-0.38$ & $\begin{array}{c}\text { Arctic Central } \\
\text { Basin }\end{array}$ & $\begin{array}{l}\text { Kanhai et al. } \\
\qquad(2018)\end{array}$ \\
\hline sediment & 5108-10908 & $\begin{array}{c}200-2200 \\
(0.27-6.20 \\
\mathrm{p} / \mathrm{g})\end{array}$ & Mariana Trench & This study \\
\hline sediment & $2783-5570$ & $\begin{array}{c}44-3463.71 \\
(0.04-6.59 \\
\mathrm{p} / \mathrm{g})\end{array}$ & $\begin{array}{c}\text { HAUSGARTEN } \\
\text { observatory in } \\
\text { the Arctic }\end{array}$ & $\begin{array}{l}\text { Bergmann et al. } \\
\text { (2017) }\end{array}$ \\
\hline sediment & $900-1000$ & $28-80$ & $\begin{array}{l}\text { SW Indian } \\
\text { Ocean }\end{array}$ & $\begin{array}{l}\text { Woodall et al. } \\
\qquad \text { (2014) }\end{array}$ \\
\hline sediment & $1400-2200$ & $120-800$ & NE Atlantic & $\begin{array}{l}\text { Woodall et al. } \\
\qquad(2014)\end{array}$ \\
\hline sediment & $300-1300$ & $200-700$ & Mediterranean & $\begin{array}{l}\text { Woodall et al. } \\
\text { (2014) }\end{array}$ \\
\hline sediment & $2419-4881$ & $0-40$ & $\begin{array}{l}\text { Polar Front of the } \\
\text { Southern Ocean }\end{array}$ & $\begin{array}{l}\quad \text { Van } \\
\text { Cauwenberghe } \\
\text { et al. (2013) }\end{array}$ \\
\hline
\end{tabular}

The colourful microplastics were also widely identified in hadal sediments (Fig. 3). Like the bottom water, microfibres were abundant in the sediments (Table S-4). Microplastic abundances in hadal sediments ranged from 200 to 2200 pieces per litre. Higher abundances were commonly found in deeper hadal sediments, especially at depths of 7000-11000 $\mathrm{m}$. The maximum value reached 2200 pieces per litre at the depth of $7180 \mathrm{~m}$, followed by 2000 pieces per litre at $9373 \mathrm{~m}$. We compared the microplastic abundances of our sediment samples with that in deep sea sediments reported from other studies (Van Cauwenberghe et al., 2013; Woodall et al., 2014; Bergmann et al., 2017) (Table 1). The maximum abundance of microplastics detected in the Mariana sediments is twice as high as that reported in deep sea sediments from the Atlantic Ocean and the Mediterranean Sea (70-800 pieces per litre, Woodall et al., 2014), and twenty times more than that in deep sea sediments from the SW Indian Ocean and the Southern Atlantic (Van Cauwenberghe et al., 2013; Woodall et al., 2014). However, it is comparable to Arctic deep sea sediments, where the highest abundance of microplastics recorded was 3463.71 pieces per litre, at a depth of $2783 \mathrm{~m}$ (Bergmann et al., 2017).

Eleven different polymers, including polyvinyl chloride, polyamide, rayon, acrylonitrile butadiene styrene, polypropylene, polyethylene, polystyrene, aromatic polyamide, polyethylene terephthalate, polyester, and polyurethane were identified from the Mariana samples (Fig. 2). Polyethylene terephthalate accounted for the largest proportion (19\%) in hadal bottom waters, followed by polyamide $(14 \%)$, polyvinyl chloride $(13 \%)$, polyurethane $(12 \%)$, polyester $(11 \%)$, polystyrene (11\%), and rayon (9\%) (Fig. 2). In the sediments, polyester accounted for the largest proportion (19\%), followed by polypropylene $(15 \%)$, polyurethane $(14 \%)$, polyamide (12 $\%)$, polyamide $(12 \%)$, polyvinyl chloride $(10 \%)$, rayon (10 $\%)$, and polyethylene (9\%) (Fig. 3). Microplastic compositions from our study are different from those previously reported in other deep sea environments. For example, polypropylene and polyethylene are most abundant in the water column of the North Pacific Ocean (Rios et al., 2007). Polyester, followed by acrylic fibres dominate in sediments from the deep NE 
Atlantic, Mediterranean, and SW Indian Ocean (Woodall et al., 2014), while chlorinated polyethylene, polyamide and polypropylene account for $76 \%$ in Arctic sediments (Bergmann et al., 2017). Such compositional differences probably reflect the differences in the source of microplastics in various deep sea areas, and/or the difference in the vertical transport processes among various microplastics. Although polymer type in this study does not unequivocally establish the source of plastic particles, it could provide useful information. All the synthetic polymers found in this study could be derived from textiles, ropes, fishing gear (nets, lines etc.), plastic beverage bottles, and packaging materials (Andrady, 2011; Claessens et al., 2011; Napper and Thompson, 2016), while rayon may also be used in personal hygiene products and cigarette filters (Woodall et al., 2014).

The high abundance of microplastics in Mariana bottom water and sediments may be derived from industrialised regions in the Northwest Pacific (Jamieson et al., 2017) and the North Pacific Subtropical Gyre, so called "Great Pacific Garbage Patch" (Kaiser, 2010), where the Pacific surface circulation, i.e. the Eastern Subtropical Mode Water and Subtropical Mode Water, may lead to long distance transport of microplastics to Mariana trench, respectively (Tseng et al., 2016). Except for polypropylene and polyethylene, all the polymer types recorded in this study are negatively buoyant (Andrady, 2011) and would eventually sink. Colonisation by organisms, adherence to phytoplankton, and aggregation with organic debris and small organic particles will eventually enhance settling (Zarfl and Matthies, 2010; Katija et al., 2017). It was reported that the vertical transportation rate of surface-derived material can be up to 64-78 m per day in the Japan Trench (Oguri, 2013). A relatively rapid deposition of sediments has also been reported in the hadal zone of Mariana Trench (Glud et al., 2013), probably due to erratic downslope sediment transport triggered by occasional earthquakes and/or repeated resuspension and deposition of material (Itou et al., 2000), which could result in increased accumulation of microplastics in the hadal zone. In addition, the narrow V-shaped topography of the trench may also enhance the downslope flux of microplastics into the hadal zone (Nunoura et al., 2015). Bottom currents, together with propagating internal tides, may further enhance the downwelling of particles and foster the accumulation of microplastics in the Mariana Trench (Taira et al., 2004; Turnewitsch et al., 2014).

Our results confirm the presence of microplastics throughout the bottom water and sediments of the Southern Mariana Trench. We suggest that a part of the 'missing' microplastics in the ocean could have been transferred to the deep ocean. Given the vastness of the hadal zone and the high abundance of microplastics in all of the bottom water and sediments, the hadal zone could be one of the largest microplastic sinks on Earth. It has been demonstrated that microplastics could be available to every level of the food web (Cedervall et al., 2012; Rillig, 2012; Mattsson et al., 2014; Avio et al., 2017). Ingestion of microplastics may result in adverse health effects, such as internal blockage and endocrine dysfunction (Wright et al., 2013, Kershaw et al., 2015). Recently, microplastics were reported to be found in crustaceans from the deep trenches (A.J. Jamieson in The Guardian newspaper report by Taylor, 2017). Further work to evaluate the impacts of microplastics on fragile hadal ecosystems is urgently needed in the future.

\section{Acknowledgements}

Funding for this study was provided by the Strategic Priority Research Program of the Chinese Academy of Sciences (XDB06020000), National Key Research and Development plan of China (2016YFC0304900) and the National Key Basic Research Program of China (Grant No. 2015CB755905).

Editor: Eric H. Oelkers

\section{Additional Information}

Supplementary Information accompanies this letter at http:// www.geochemicalperspectivesletters.org/article1829.

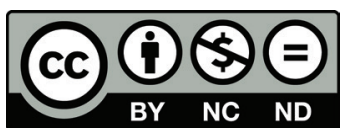

This work is distributed under the Creative Commons Attribution Non-Commercial No-Derivatives 4.0 License, which permits unrestricted distribution provided the original author and source are credited. The material may not be adapted (remixed, transformed or built upon) or used for commercial purposes without written permission from the author. Additional information is available at http://www.geochemicalperspectivesletters.org/ copyright-and-permissions.

Cite this letter as: Peng, X., Chen, M., Chen, S., Dasgupta, S., Xu, H., Ta, K., Du, M., Li, J., Guo, Z., Bai, S. (2018) Microplastics contaminate the deepest part of the world's ocean. Geochem. Persp. Let. 9, 1-5.

\section{References}

ANDRADY, A.L. (2011) Microplastics in the marine environment. Marine Pollution Bulletin 62, 1596-1605.

Arthur, C., BAKer, J., BAMFord, H. (Eds.) (2009) Proceedings of the International Research Workshop on the Occurrence, Effects and Fate of Microplastic Marine Debris. Sept. 9-11, 2008. NOAA Technical Memorandum NOS-OR\&R-30.

Avio, C.G., Gorbi, S., Regoli, F. (2017) Plastics and microplastics in the oceans: From emerging pollutants to emerged threat. Marine Environmental Research 128, 2-11.

Barnes, D.K., Galgani, F., Thompson, R.C., Barlaz, M. (2009) Accumulation and fragmentation of plastic debris in global environments. Philosophical Transactions of the Royal Society B: Biological Sciences 364, 1985-1998.

Bergmann, M., Wirzberger, V., Krumpen, T., Lorenz, C., Primpke, S., TeKman, M.B., GerdTs, G. (2017) High Quantities of Microplastic in Arctic Deep-Sea Sediments from the HAUSGARTEN Observatory. Environmental Science \& Technology 51, 11000-11010.

Cedervall, T., Hansson, L.A., Lard, M., Frohm, B., Linse, S. (2012) Food chain transport of nanoparticles affects behaviour and fat metabolism in fish. Plos One 7, doi: 10.1371/journal.pone.0032254.

CHAE, Y., AN, Y.J. (2017) Effects of micro-and nanoplastics on aquatic ecosystems: Current research trends and perspectives. Marine Pollution Bulletin 124, 624-632.

Claessens, M., Meester, S.D., Landuyt, L.V., Clerck, K.D., Janssen, C.R. (2011) Occurrence and distribution of microplastics in marine sediments along the Belgian coast. Marine Pollution Bulletin 62, 2199-2204.

Courtene-Jones, W., Quinn, B., Gary, S.F., MogG, A.O., NArayanasWAMY, B.E. (2017) Microplastic pollution identified in deep-sea water and ingested by benthic invertebrates in the Rockall Trough, North Atlantic Ocean. Environmental Pollution 231, 271-280.

Cózar, A., Echevarría, F., GonzÁlez-Gordillo, J.I., Irigoien, X., Úbeda, B., Hernández-León, S., Palma, A.T., Navarro, S., García-de-Lomas, J., Ruiz, A., Fernández-De-Puelles, M.L., Duarte, C.M. (2014) Plastic debris in the open ocean. Proceedings of the National Academy of Sciences 111, 10239-10244.

Dasgupta, S., Peng, X., Chen, S., Li, J., Du, M., Zhou, Y.-H., Zhong, G., $\mathrm{XU}_{\mathrm{U}}$ H., TA, K. (2018) Toxic anthropogenic pollutants reach the deepest ocean on Earth. Geochemical Perspectives Letters 7, 22-26.

Desforges, J.P.W., Galbraith, M., Dangerfield, N., Ross, P.S. (2014) Widespread distribution of microplastics in subsurface seawater in the NE Pacific Ocean. Marine Pollution Bulletin 79, 94-99.

Eriksen, M., Maximenko, N., Thiel, M., Cummins, A., Lattin, G., Wilson, S., Rifman, S. (2013) Plastic pollution in the South Pacific subtropical gyre. Marine Pollution Bulletin 68, 71-76. 
Fujioka, K., Okino, K., Kanamatsu, T., Ohara, Y. (2002) Morphology and origin of the Challenger Deep in the Southern Mariana Trench. Geophysical Research Letters 29, doi: 10.1029/2001GL013595.

Geyer, R., JAmbeck, J.R., LAW, K.L. (2017) Production, use, and fate of all plastics ever made. Science Advances 3, doi: 10.1126/sciadv.1700782.

Glud, R.N., WenzhÖFer, F., Middelboe, M., Oguri, K., Turnewitsch, R., Canfield, D.E., Kitazato, H. (2013) High rates of microbia carbon turnover in sediments in the deepest oceanic trench on Earth. Nature Geoscience 6, 284-288.

Goldstein, M.C. (2012) Abundance and ecological implications of microplastic debris in the North Pacific Subtropical Gyre. Doctoral dissertation, University of California, San Diego.

Hammer, J., KraAK, M.H.S., PARsons, J.R. (2012) Plastics in the marine environment: the dark side of a modern gift. In: Whitacre, D. (Ed.) Reviews of Environmental Contamination and Toxicology. Reviews of Environmental Contamination and Toxicology (Continuation of Residue Reviews), volume 220. Springer, New York, 1-44.

Hidalgo-Ruz, V., Gutow, L., Thompson, R.C., Thiel, M. (2012) Microplastics in the marine environment: a review of the methods used for identification and quantification. Environmental Science \& Technology 46, 3060-3075.

ItOU, M., MATSUMURA, I., NORIKI, S. (2000) A large flux of particulate matter in the deep Japan Trench observed just after the 1994 Sanriku-Oki earthquake. Deep Sea Research Part I: Oceanographic Research Papers 47, 1987-1998.

IVAR Do Sul, J.A., CostA, M.F. (2014) The present and future of microplastic pollution in the marine environment. Environmental Pollution $185,352-364$.

Jambeck, J.R., Geyer, R., Wilcox, C., Siegler, T.R., Perryman, M., ANDrady, A., NARAYAN, R., LAW, K.L. (2015) Plastic waste inputs from land into the ocean. Science 347, 768-771.

Jamieson, A.J., Fujin, T., Mayor, D.J., Solan, M., Priede, I.G. (2010) Hadal trenches: the ecology of the deepest places on Earth. Trends in Ecology \& Evolution 25, 190-197.

Jamieson, A.J., Malkocs, T., Piertney, S.B., Fujil, T., Zhang, Z. (2017) Bioaccumulation of persistent organic pollutants in the deepest ocean fauna. Nature Ecology \& Evolution 1, doi: 10.1038/s41559-016-0051.

KAISER, J. (2010) The dirt on ocean garbage patches. Science 328, 1506

KanHai, L.D.K., GÅrdfeldT, K., Lyashevska, O., HassellöV, M. ThOMPsOn, R.C., O'CONNOR, I. (2018) Microplastics in sub-surface waters of the Arctic Central Basin. Marine Pollution Bulletin 130, 8-18.

Katija, K., Choy, C.A., Sherlock, R.E., Sherman, A.D., Robison, B.H. (2017) From the surface to the seafloor: How giant larvaceans transport microplastics into the deep sea. Science Advance 3, doi: 10.1126 sciadv.1700715.

KERSHAW, P.J., ROCHMAN, C.M. (2015) Sources, fate and effects of microplastics in the marine environment: part 2 of a global assessment. Reports and studies-IMO/FAO/Unesco-IOC/WMO/IAEA/UN/UNEP Joint Group of Experts on the Scientific Aspects of Marine Environmental Protection (GESAMP) eng no. 93.

Mattsson, K., Ekvall, M.T., Hansson, L.A., Linse, S., Malmendal, A., Cedervall, T. (2014) Altered behavior, physiology, and metabolism in fish exposed to polystyrene nanoparticles. Environmental Science $\mathbb{E}$ Technology 49, 553-561.

NAPPER, I.E., ThOMPSON, R.C. (2016) Release of synthetic microplastic plastic fibres from domestic washing machines: effects of fabric type and washing conditions. Marine Pollution Bulletin 112, 39-45.

Nunoura, T., Takaki, Y., Hirai, M., Shimamura, S., Makabe, A., KoIde, O., SunAmura, M. (2015) Hadal biosphere: insight into the microbial ecosystem in the deepest ocean on Earth. Proceedings of the National Academy of Sciences 112, 1230-1236.

Oliveira, M., Ribeiro, A., Guilhermino, L. (2012) Effects of exposure to microplastics and PAHs on microalgae Rhodomonas baltica and Tetraselmis chuii. Comparative Biochemistry and Physiology Part A, S19-S20.

Oguri, K., Kahamura, K., Sakaguchi, A., Toyofuku, T., Kasaya, T., Murayama, M., Fujikura1, K., Glud, N.R., Kitazato, H. (2013) Hadal disturbance in the Japan Trench induced by the 2011 Tohoku-Oki Earthquake. Scientific Reports 3, doi: 10.1038/srep01915.

RILLIG, M.C. (2012) Microplastic in terrestrial ecosystems and the soil? Environmental Science \& Technology 46, 6453-6454.

Rios, L.M., Moore, C., Jones, P.R. (2007) Persistent organic pollutants carried by synthetic polymers in the ocean environment. Marine Pollution Bulletin 54, 1230-1237.

TAira, K., KitagaWA, S., YAmashiro, T., Yanagimoto, D. (2004) Deep and bottom currents in the Challenger Deep, Mariana Trench, measured with super-deep current meters. Journal of Oceanography 60, 919-926.
TAYLOR, M. (2017) "Plastics found in stomachs of deepest sea creatures". The Guardian, 15 November, https://www.theguardian.com/ environment/2017/nov/15/plastics-found-in-stomachs-ofdeepest-sea-creatures.

Thompson, R.C., Olsen, Y., Mitchell, R.P., Davis, A., Rowland, S.J., JoHN, A.W., RusselL, A.E. (2004) Lost at sea: where is all the plastic? Science 304, 838-838.

Tseng, Y.H., Lin, H., Chen, H.C., Thompson, K., Bentsen, M., Böning, C.W., ET AL. (2016) North and equatorial Pacific Ocean circulation in the core-ii hindcast simulations. Ocean Modelling 104, 143-170.

Turnewitsch, R., Falahat, S., Stehlikova, J., Oguri, K., Glud, R.N., Middelboe, M., Kitazato, H., Wenzhöfer, F., Ando, K., Fujio, S., Yanagimoto, D. (2014) Recent sediment dynamics in hadal trenches: evidence for the influence of higher frequency (tidal, near-inertial) fluid dynamics. Deep Sea Research Part I: Oceanographic Research Papers 90, 125-138.

Van Cauwenberghe, L., Vanreusel, A., Mees, J., Janssen, C.R. (2013) Microplastic pollution in deep-sea sediments. Environment Pollution 182, 495-499.

Van Sebille, E., Wilcox, C., Lebreton, L., Maximenko, N., Hardesty, B.D., Van Franeker, J.A., Eriksen, M., Siegel, D., Galgani, F., LAW, K.L. (2015) A global inventory of small floating plastic debris. Environmental Research Letters 10, doi: 10.1088/1748-9326/10/12/124006.

Woodall, L.C., Sanchez-Vidal, A., Canals, M., Paterson, G.L., Coppock, R., Sleight, V., Calafat, A., Rogers, D.A., Narayanaswamy, E.B., ThOmpson, R.C. (2014) The deep sea is a major sink for microplastic debris. Royal Society Open Science 1, doi: 10.1098/rsos.140317.

Wright, S.L., Thompson, R.C., GallowaY, T.S. (2013) The physical impacts of microplastics on marine organisms: a review. Environment Pollution 178, 483-492.

Zarfl, C., Matthies, M. (2010) Are marine plastic particles transport vectors for organic pollutants to the Arctic? Marine Pollution Bulletin 60, 1810-1814

ZHAO, S., ZHU, L., WANG, T., LI, D. (2014) Suspended microplastics in the surface water of the Yangtze Estuary System, China: first observations on occurrence, distribution. Marine Pollution Bulletin 86, 562-568. 